\title{
SCENARIO ANALYSIS UNDER CHAOS
}

\author{
Magdalena ADAMUS \\ Cracow University of Economics \\ E-mail: lena.adamus@gmail.com \\ Piotr MARKIEWICZ \\ Cracow University of Economics \\ E-mail: piotr.markiewicz@uek.krakow.pl
}

doi:10.13165/IE-13-7-2-03

\begin{abstract}
The aim of this study is to present how to modify classic scenario methods in order to adjust them to extremely unpredictable, chaotic conditions. It is an attempt to prove how it is possible to gradually adapt to changes of environment and indicate methods through which such adaptation can be more efficient. Due to the dynamic and complex character of interactions that take place in such unstable conditions, application of tools offered by scenario methods modified with some elements originating from studies on chaos has been proved to be effective.
\end{abstract}

JEL classification: G32, C73.

Keywords: uncertainty, scenario analysis, evolution, strategic management.

Reikšminiai žodžiai: neapibrěžtumas, scenarijų analizè, evoliucija, strateginis valdymas.

\section{Introduction}

The aim of this study is to present how to modify classic scenario methods in order to adjust them to extremely unpredictable, chaotic conditions. It is an attempt to prove how it is possible to gradually adapt to changes of environment and indicate methods through which such adaptation can be more efficient. Due to the dynamic and complex character of interactions that take place in such unstable conditions, it has been proved that application of tools offered by scenario methods modified with some elements originating from studies on chaos allow to overcome difficulties. The hypothesis of the study is that the proper linearization of process that might be seen as nonlinear allows to model such processes effectively and to introduce an order that facilitates development of strategies aiming at achieving established goals. In the first section of this study the role of scenario analysis and its place within strategic planning and management is analysed. The second part is dedicated to chaos and possibilities to adapt to such chaotic conditions using scenario methods effectively. Nowadays, environment becomes increasingly unstable and this article presents how to use evolutionary approach in order to apply learning principle and improve recognition of most favourable strategies. 


\section{Scenario analysis as a tool of strategic management}

The strategic management is considered to be one of the newest concepts of management, although its history can be dated back to more than 40 years. It is an area of both knowledge and practical activities. Initially, the interest focused mainly on the process of formulating development policies and long-term operating principles of organisation. Along with the further development of the environment and industry, the increasing attention has been paid to the problem of strategy implementation. One of important aspects of the strategic management is the instrumental aspect expressed in a rich set of methods and techniques applied on particular stages of the strategic management process. Strategic planning is a process in which the rational analysis of current situation and future opportunities and threats lead to formulating intentions, strategies, measures and objectives. Intentions, strategies, measures and objectives reveal how the organisation optimally exploiting existing resources takes opportunities generated by the environment and defends itself from threads (Kreikebaum, 1997).

Important values of the strategic planning understood in this way are as follows:

- Reduction of uncertainty arising from the environment;

- Understanding the risk and uncertainty as a permanent aspect of "game with the environment" for development or survival.

Taking into account the dynamics of changes in the environment as well as in the organisation itself, it can be concluded that the strategic planning means preparation and decision making. These decisions concern basic and directional objectives of the organisation as well as resources and methods required to obtain them. These decisions are also of extreme importance to the existence of the organisation and regulate its relations with the environment. The basic tools determining the direction and structure of the development of the organisation are strategies. Therefore, the objective of the strategic planning is to generate and select such strategies that allow obtaining established objectives and implementation of a mission defined.

Figure 1 presents development stages of the strategic planning and the role of scenario planning (scenario methods) in this development.

Figure 1. Evolution of long range planning approaches

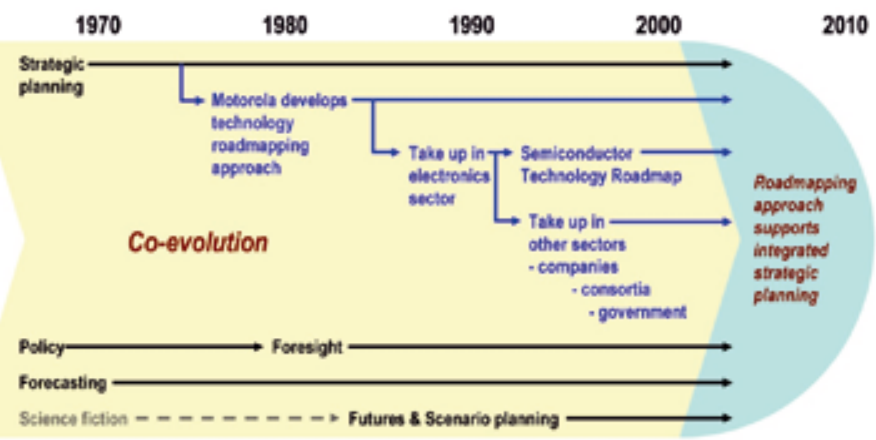

Source: R. Phaal, C.J.P. Farrukh, D.R. Probert, 2001. 


\subsection{Modern techniques for creating scenarios}

Development of modern techniques for creating scenarios occurred in the postwar years of the $20^{\text {th }}$ century. The dominant role was played by two centres: the USA and France. Herman Kahn is commonly recognised as a founder of the method for developing scenarios. During his work for the Rand Corporation (a research group originating from the cooperation between the USA Air Force and the Douglas Aircraft) in the 50s, he used new, wider capacities of computer data processing, game theory and demand for simulation models for the US army to revolutionise the military strategic planning of the USA (Lisiński, 2004: 105).

In 1961, Kahn established the Hudson Institute and started works on the implementation of his concept of scenarios development into the social policy. The first documented application of this method in the business world was the strategy of Royal Dutch Shell, implemented between 1972 and 1973.

The development of scenarios may involve:

- crisis management - e.g., scenarios being a simulation of future crisis situations in civil defense are used to design and test systems and the equipment in order to adjust them to the requirements of the situation and increase the level of readiness;

- science - scenarios are used, among others, to transmit the results of used models and theories with increasing complexity in a way facilitating their understanding, e.g., scenarios concerning climatic changes or economic scenarios created with computer models;

- social policy - scenarios are applied to engage representatives of various societies in taking and implementing political decisions;

- professional development of the vision of the future - scenarios implemented by expert institutions in order to spread ideas on critic tendencies shaping the future and promote methodology of researches on the future;

- education - through engaging institutions promoting researches and developing theories and methodologies of studies on the future;

- business - scenarios are applied to the long-term planning.

The successful application of scenarios depends largely on the appropriate selection of scenario type to a particular application. The objective of scenarios can be expressed as a two-way relation:

- solving a single problem or increasing the ability to survive in the long-term process;

- stimulating an organisation to perform researches or to solve a particular problem - taking a particular decision, which leads to the development of the following matrix of areas, where scenarios can be applied: solving a particular problem, development of strategy, forecasting, adaptive learning of organisation.

The essence of scenario analysis includes a description of phenomena and indication of its logical and comprehensive consequences and then determining ways of how will they develop in the future. Therefore, the starting point is the state of the phenome- 
na, for which the future alternative sequence of events is stipulated, finding its concrete expression at the final stage of the application of methods in a set of possible visions of the future. Thus, the scenarios created are a set of events linked into a logical, usually chronological, sequence.

The basis determining the mode of the application of the scenario analysis is their division into four basic groups:

- $\quad$ scenarios of possible events;

- $\quad$ simulation scenarios;

- scenarios of environmental conditions;

- $\quad$ scenarios of process in the environment.

The classification of the scenarios can be divided into three categories and six types according to the type of question posed (Borjeson, Hojer, Dreborg, Ekvall, Finnveden, 2005: 14):

- $\quad$ forecasting (what will happen) - prognosis and what if?;

- $\quad$ seeking (what might happen) - external and strategic;

- normative (how to implement the objective assumed) - preservative and transforming.

The typology of the scenarios according to the criteria mentioned above is presented in figure 2 .

Figure 2. Typology of scenarios in three categories

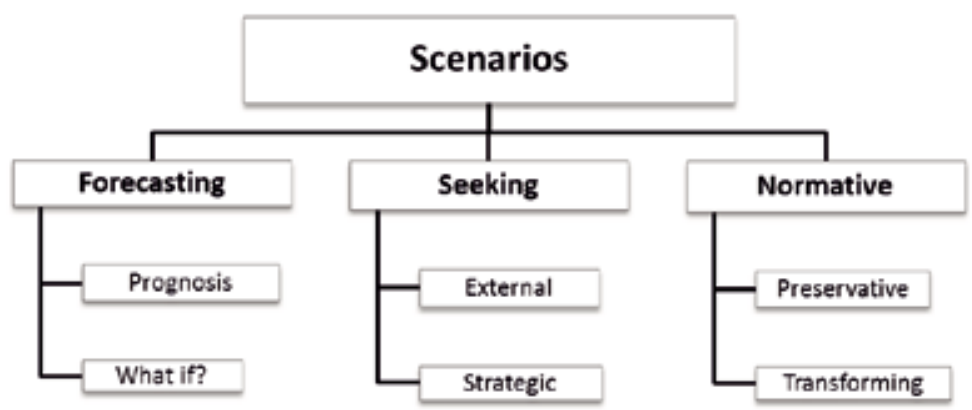

Source: Own study based on: Borjeson, Hojer, Dreborg, Ekvall, Finnveden, 2005.

\subsection{Selection of optimal strategy}

The methods used in developing a strategy can be classified from the perspective of their application in the strategic planning process. Assuming that the strategic planning includes two research sub-processes - strategic analysis and strategy design - the strategic planning methods shall be subordinated to these two processes. Therefore, a group of methods is obtained allowing for the strategic analysis; however, the strategic direction should not be indicated that should be chosen under such circumstances and strategic potential. The second group of methods are those, which after the strategic ana- 
lysis indicate which strategy shall be chosen by the organisation. This group includes the SPACE matrix and the so called portfolio methods (the BCG matrix, the GE matrix and the ADL matrix).

The scenario methods, which are of interest here, are used to analyse the relations between the phenomena present in the environment, research on impacts of these phenomena on the organisation and to characterise different points of view in a particular situation. These methods are used for long-term forecasts in situations, when:

- there is not enough knowledge about regularities of analysed phenomena;

- the phenomenon is not continuous and, therefore, there is a gap between the past and the present as well as between the present and the future;

- the phenomena cannot be formally described or are of qualitative nature.

Based on these forecasts, it is possible to define strategies for particular scenarios of environmental conditions. In table 1 , four variants (techniques) for strategy selection are presented.

Table 1. Variants of strategy selection in the scenario planning

\begin{tabular}{|l|l|}
\hline \multicolumn{1}{|c|}{ Variants } & \multicolumn{1}{c|}{ Characteristics } \\
\hline Variant I & $\begin{array}{l}\text { identification of environmental scenarios developed individually (without linkage); } \\
\text { development of strategy for an organisation for each scenario individually; } \\
\text { selection of scenario and strategy with the highest expected value. }\end{array}$ \\
\hline Variant II & $\begin{array}{l}\text { identification of scenarios developed in a form of dendrite with distinguished } \\
\text { stages for which the probabilities have been determined; } \\
\text { development of strategy for each branch of the dendrite together with probabi- } \\
\text { lities and the expected value; } \\
\text { selection of scenario and strategy with the highest expected value. }\end{array}$ \\
\hline Variant III & $\begin{array}{l}\text { identification of scenarios developed in a form of dendrite with distinguished } \\
\text { stages for which the probabilities have been determined; } \\
\text { development of strategy for each branch of the dendrite together with probabi- } \\
\text { lities and the expected value; } \\
\text { in the second phase analysis of the dendrite of potential strategies, corrections } \\
\text { of strategies with possible options for particular branches of the dendrite and } \\
\text { for stages distinguished; } \\
\text { selection of a strategy in a form of a branch of dendrite with the highest expected } \\
\text { value. }\end{array}$ \\
\hline Variant IV & $\begin{array}{l}\text { development of a universal strategy for as many scenarios as possible; } \\
\text { division of scenarios into stages including a possibility to reduce the number } \\
\text { of scenarios. }\end{array}$ \\
\hline
\end{tabular}

Source: Krupski, R. and Sus - Januchowska A. Wariacje na Temat Planowania Scenariuszowego, in: Stankiewicz, M. J. Zarzadzanie Organizacjami w Gospodarce Opartej na Wiedzy. Toruń: Wyzwania strategiczne wobec organizacji, Dom Organizatora TNOiK, 2008.

The variants of the strategy selection presented above do not cover the entire spectrum of ways to solve the strategy selection issue, but are one of possible approaches to that subject. 


\section{Organisation in the environment}

\subsection{Unstable environment}

Nowadays, the analysis of decision problems under uncertainty has been expanded to include additional factors corresponding to the changing environment and difficulties related to both an excess of information and problems with its efficient processing, and, on the other hand, constantly changing situation, which makes it difficult to perform prognosis and gradually adapt to changing conditions, not even speaking about trials to shape events that go beyond even the most profound uncertainty (Kotler, Casilione, 2009). Therefore, there arises a serious problem and at the same time a specific research question how to behave in situations, which only to some minor degree reflect what has already been known from the experience - how to prepare to create new strategies, when the current ones have been destabilised? Particularly, the question concerns the possibility of applying the already known tools and transforming them in line with new circumstances. The variability of decision conditions excludes adoption of the static perspective due to the fact that it is difficult to indicate the period during which the conditions will remain unchanged. Therefore, it appears to be useful to search for the approach, additionally including parameters related to the variability in time.

The dynamic approach includes primarily the ability to learn based on the previous experience. Learning, depending on the approach, can be formally described in several different ways, however, each time it assumes the ability to accumulate information, thanks to repetition of the same of analogous games (decision situations) or problems that could be categorised into one subjectively isolated type (Arrow, 1958). However, under chaos the probability of particular forecasted events, even if in fact it is not equal, is subjectively evaluated as such and, therefore, the entropy of a given system, at least at the level of perception, is maximum.

If one has to deal with the decision problems solved under chaos, it might be more favourable to include some elements of the information theory, and, more precisely, the concept of entropy defined for the purposes of the communication theory by C.E. Shannona (1948). According to definitions adopted both in thermodynamics and the theory of language, the entropy is a measure of uncertainty of a given system and, therefore, it can be called a measure of chaos in this system. The concept expresses a belief that the more similar the probabilities of particular events in the given system are, the higher the entropy is. It becomes the highest, when the probabilities are equal, which is consistent with an intuition about phenomena, such as the risk. The entropy shall be defined as follows:

For a given system $Z$, in which the following events may occur: $Z_{1}, Z_{2}, \ldots, Z_{m}$, each with some given probability $\mathrm{P}\left(\mathrm{Z}_{1}\right), \ldots, \mathrm{P}\left(\mathrm{Z}_{\mathrm{m}}\right)$, the entropy shall be expressed with the following formula:

$$
\mathrm{H}(\mathrm{Z})=-\sum_{j=1}^{m} P\left(Z_{j}\right) \log _{2} P\left(Z_{j}\right) .
$$


The entropy is always a non-negative value, however, it may be equal to zero, when the uncertainty is completely reduced and events occur with the probability equal to 1 $[\mathrm{H}(\mathrm{Z}) \geq 0]$. The concept of the entropy facilitates comparing decision situations in terms of uncertainty, but it also allows examining to what extent the researches planned and performed prior to decision could reduce the uncertainty and, therefore, help determine whether the investment in gathering information is cost effective from the perspective of reducing risk (see Beer, 1966: 51; Mynarski, 1974: 119; Mynarski, 1989: 146; Karwacki, Konarzewska, 1997:24). These authors propose also to include in the formula applied the possibility of additional researches that could reduce the uncertainty of a given situation $Z$ and increase the probability of finding an optimal decision. Therefore, the general formula shall include conditional probabilities of particular events of the situation $Z$, provided a given cognitive activity $X$ and, therefore, the following formula is obtained:

$$
\mathrm{I}(\mathrm{X}, \mathrm{Z})=\mathrm{H}(\mathrm{Z})-\mathrm{H}(\mathrm{Z} \mid \mathrm{X})
$$

where:

$\mathrm{H}(\mathrm{Z})$ - entropy of an event $\mathrm{Z}$;

$\mathrm{H}(\mathrm{Z} \mid \mathrm{X})$ - entropy of an event $\mathrm{Z}$ provided $\mathrm{X}$.

In general, the following formula is obtained:

$$
\mathrm{I}(\mathrm{X}, \mathrm{Z})=-\sum_{j=1}^{m} P\left(\mathbf{Z}_{j}\right) \log _{2} P\left(\mathbf{Z}_{j}\right)-\sum_{j=1}^{m} P\left(Z_{j} \mid B_{j}\right) \log _{2} P\left(Z_{j} \mid B_{j}\right)
$$

In such system, it can be assumed that the entropy depends on the probability distribution of the components of the given system and, therefore, it is possible to detect the risk of a particular decision situation. Despite this, it is not and cannot be understood as a tool for solving the decision-making problem due to the fact that it cannot capture the concept of utility and, therefore, also benefits from making one rather than another choice (Karwacki, Konarzewska, 1997: 26).

\subsection{Levels of uncertainty}

Of course, the degree of uncertainty can be graded and, depending on the level, it is necessary to apply different methods for coping with the uncertainty. Below, an analysis distinguishing four levels of uncertainty and appropriate methods of adapting actions to the uncertain circumstances are briefly presented (Courtney, Kirkland, Viguerie, 2000; Kotler, Caslione, 2009). The authors of the characteristics of the uncertainty presented below proposed to adopt the scenario analysis, however, the basic definition of the scenario they apply can be reduced to the background of events, on which the strategy is defined, that is the complete and exhaustive plan describing the choice situation comprehensively.

Level 1: The resource of information possessed is large enough to rely on a single strategy, which could be developed with standard (typical) methods of reasoning and analysis. Level 2: The future must be described in more than one alternative version of 
events. The information does not allow selecting one particular strategy, but allows ascribing weights (probabilities) to particular scenarios. However, none of the strategies exactly matches the requirements of the situation. Level 3: Several variables can be distinguished; however, it is not possible to determine how the situation would evolve. The data available are too limited to describe precisely the scenarios of the events and, therefore, it is necessary to develop several scenarios that could be next modified, depending on the situation. Level 4: Described by the authors (Courtney, Kirkland, Viguerie, 2000; Kotler, Caslione, 2009) as the actual uncertainty, circumstances are completely unpredictable and, therefore, it is impossible to determine any reasonable number of scenarios and strategies corresponding to them. It seems that usually it is possible to reduce this kind of uncertainty to one of lower levels, however, not always.

Some authors (Courtney, Kirkland, Viguerie, 2000) also noted that under uncertainty it is possible to adopt one of the three attitudes, namely, it is possible to shape the situation (e.g., see the PARTS model - Brandenburger, Nalebuff, 1995), to adapt to the situation (see below) or adopt the waiting strategy in order to take actions in more favourable circumstances. This time, however, shall be dedicated to intense preparations and an attempt to understand the situation in detail in order to obtain an advantage afterwards. These attitudes are not mutually exclusive, but can complement each other. When it is impossible to shape circumstances, making decisions a subject can modify the strategy, at least partially, into adaptation. Furthermore, each of these attitudes can be adopted at each level of uncertainty, while strategies adopted with the increasing uncertainty are characterised by the increasing generality (Beinhocker, 1999) and gaps can be filled if there are new information available.

\subsection{Chaos}

In mathematics, chaos is defined as a strong influence of initial conditions on the result obtained - the so called deterministic chaos. More generally, it could be said that these are all events and circumstances that destabilise already adopted strategies and make the previously acquired knowledge and experiences less useful for taking decisions in the current decision problems. It is so, because variations of individual random variables exhibit no clear regularities that could be used to predict their future distribution or these regularities are too complex to be captured in a simple formula (Butler, 1990; Murphy, 1996). One of the methods for analysing chaotic and nonlinear systems is the chaos theory (Levy, 1994). The theory was formulated primarily for natural sciences and its mathematical apparatus is adapted to the requirements of theses sciences. It seems, however, that some applications of that theory are possible also in social sciences and, particularly, in economics. This application must be necessarily limited because sources of uncertainty are identified differently in social interactions than in relations studied within natural sciences.

First of all, one of the main problems is related to the definition of initial conditions: while in experiments performed in natural sciences it is possible to define initial conditions precisely, in social sciences both initial conditions and the further development of events is conditioned by behaviour of individual subjects in a given situation. 
Furthermore, according to the assumptions adopted in that theory, the organisations participating in such situation are not fixed as constant, but are subject to internal transformations (Levy, 1994) and, therefore, the nonlinearity covers not only particular scenarios, but also an organisation itself, which is not a stable system anymore (Thomas, Mengel, 2008).

However, even if the chaos theory involves the assumption associated with excessive, postmodern consequences, including the phenomena of extreme uncertainty itself, it should be fruitful and in the broader perspective it might appear even necessary for formulating medium and long-term strategies as well as for prognosis of future changes in the environment affecting the performance of the organisation.

\subsection{Evolution in dynamic and uncertain conditions}

\subsubsection{Branching processes (Galton-Watson processes)}

Modelling strategies under uncertainty and in dynamic conditions may be based on an evolutionary model, because the development of social events exhibits many similarities to the evolution in the strict sense of this word (Kauffman, 1995), even if the course of social process is affected by different conscious activities of subjects. The evolution of various technological inventions resembles the biological evolution: there are many parallel, random development branches, of which most appear to be dead ends. Furthermore, particular branches - scenarios of the development - should be understood as independent and identically distributed variables (iid). Kauffman (1995) gives an example of such development, namely, the evolution of a bicycle - through many dead ends of the evolution, the modern form was obtained, even though once it was only one of many forms. Particularly, it was a form that was not obvious to be widely adopted, similarly as cars with gasoline engines. Therefore, each strategy can be understood as an example of such branch that independently aims at obtaining possibly the highest fitness or is eliminated at one of further stages. Therefore, the development of branches can be expressed with the following formula, which focuses on the fact that at each stage there are some future states originating from initial conditions, however, it cannot be clearly established, which of these scenarios will be the "winning" one.

$$
z_{n+1}=\sum_{i=1}^{Z_{n}} X_{n, i}
$$

where:

$Z_{\mathrm{n}}$ is a state in a given period of time $n, X_{\mathrm{n}, \mathrm{i}}$ is a random variable describing the number of all branches originating from a particular node (direct consequences of the node $i$ within the period $n$ ) - all are independent and identically distributed for all $n \in\{0,1,2, \ldots\}$ and all $i \in\left\{1, \ldots, Z_{n}\right\}$. 


\subsubsection{Multiplied strategies}

External disturbances of the system causing changes of context conditions force to commence the adaptation process (Beinhocker, 1997) in order to obtain equilibrium, usually different than the equilibrium obtained previously in stable conditions. This allows not only understanding how interactions between particular subjects are shaped, but also how they change in time depending on disturbances of the entire system. Due to dynamically changing conditions, it is difficult to obtain stability using only a single strategy. It might be more efficient, assuming branching conditions, to apply a mixed strategy, which in fact is a single strategy or even focus on several various, parallel strategies (Beinhocker, 1999). Then, if one of the strategies proves to be inadequate in new circumstances, it can be replaced with another one. Of course, at each moment only one strategy is implemented, however, it is still possible to analyse what results could be obtained in a certain condition applying other monitored strategies.

It means that when the strategy chosen would prove to be unreliable and the result obtained through it would differ from the expected one, it would be easier and faster to replace such strategy with one of the parallel strategies tested. Of course, this involves costs (in a broad sense of this word), because it requires time, attention and cognitive capacities of the entity performing such analysis. However, particularly in a case of longterm problems, consisting of series of repeated rounds, the diversification of the considered strategies may prove to be beneficial, especially in open and dynamic systems that exhibit significant variations in time (Beinhocker, 1997), and the variation is, among others, a resultant of interactions between particular participants and interactions between participants and the environment. In such conditions through an internal adaptation, an organisation can better respond to threats coming from the outside and better recognise strategies that might appear to be optimal.

However, in order to effectively adapt to the dynamic and unpredictable environment, it is necessary to possess a large number of varied strategies that include various scenarios for future conditions. Assuming that the situation is dynamic, it is possible to apply evolutionary methods (Kauffman, 1995) including learning, but it has to be learning along series of parallel development paths, of which only few contribute to success. Therefore, the survival and development strategies should be as diverse as possible in order to cover as many available scenarios as it is possible. An additional aspect that is necessary when creating scenarios is subjecting them to stress tests (Beinhocker, 1999). One of methods that could be applied in such stress tests is the "premortem analysis" described in the following section.

\subsubsection{Premortem analysis}

Thanks to the approach presented in the previous section, it is possible to focus not only on a greater number of available opportunities, but also on a greater number of possible threads. Therefore, it is possible to get prepared for a high volatility of conditions that could contribute to a need of changing the currently implemented strategy and also to un- 
derstand a need of the so called "premortem analysis" (Klein, 2007; Kahneman, 2012). The analysis aims at overcoming the excessive optimism, following the acceptation of the strategy. It involves collective assessment, during which it is assumed that after implementation the strategy has failed. Klein (2007) lists subsequent stages of the entire analysis that should be included in order to perform it correctly and to avoid the analysis of reasons of failure, when it actually occurs. Its primary aim is to improve the strategy to make it consistent with conditions that might be encountered during its implementation.

The analysis shall start with the assumption that something went wrong and the strategy failed. Then, each of the persons invited shall think a moment why it has happened and express their own suspects. There is a high probability that the reasons mentioned, at least partially, are different that those that have been formulated prior to the adoption of the strategy. When all reasons are expressed, the meeting is over, however, the analysis still goes on. Based on the potential reasons formulated, it might be necessary to determine which of these factors are the most important and how to secure particular strategies against them. Klein concludes, based on the researches performed by Mitchell, Russo and Pennington (1989), that the prospective hindsight analysis allows to increase efficiency of future performance forecasts by $30 \%$.

\section{Conclusion}

The modification of the scenario analysis, based on tools more adequate for chaotic conditions, such as linearization of processes perceived as nonlinear as well as dynamic and evolutionary modelling of decision problems, allows for better understanding and obtaining better performance. At the same time, it has been shown how important it is to assume the level of complexity of external conditions in creating scenarios. This allows for developing parallel scenarios, implemented depending on the distribution of relevant random variables. By applying such approach, it is possible to understand how to adapt to extreme uncertainty that cannot be overcome, avoiding at the same time radical rejection of rationality criterion during testing developed strategies (stress tests). The study is necessarily limited. First of all, the mathematical complexity of probabilistic analysis makes it difficult to apply it in everyday life. However, even if the development of such extensive, parallel analysis is impossible in its complete form, it still might be used as an efficient tool approaching achievement of the satisfactory solution.

\section{References}

1. Arrow, K. J. Utilities, Attitudes, Choices: A Review Note. Econometrica. 1958, 26(1): 1-26.

2. Beinhocker, E. D. Strategy at the Edge of Chaos. The McKinsey Quarterly. 1997, 1: 109-118.

3. Beinhocker, E. D. On the Origins of Strategies. The McKinsey Quarterly. 1999, 4: 167-176.

4. Beer, S. Cybernetyka a Zarządzanie. Warszawa: PWN, 1966. 
5. Borjeson, L.; Hojer, M.; Dreborg, K. H.; Ekvall, T. and Finnveden, G. Towards a User's Guide to Scenarios - A Report on Scenarion Types and Scenario Techniques. Sweden: Royal Institute of Technology, 2005.

6. Brandenburger, A. M. and Nalebuff, B. J. The Right Game: Use the Game Theory to Shape Strategy. Harvard Business Review. 1995, 73(4): 57-71.

7. Butler, A. A Methodological Approach to Chaos: Are Economists Missing the Point? Federal Reserve Bank of St. Louis Review. 1990 2(72): 36-48.

8. Courtney, H. G.; Kirkland, J. and Viguerie, S. P. Strategy under Uncertainty. The McKinsey Quarterly. 2000: 81-90.

9. Kahneman, D. Pułapki Myślenia. O Myśleniu Szybkim i Wolnym. Poznań: Media Rodzina, 2012.

10. Karwacki, Z. and Konarzewska, I. Elementy Podejmowania Decyzji. Łódź: Absolwent, 1997.

11. Kauffman, S. Escaping the Red Queen Effect. The McKinsey Quarterly. 1995(1): 119129.

12. Klein, G. Perfoming a Project Premortem. Harvard Business Review. 2007: 18-19.

13. Kotler, P. and Casilione, J. A. Chaos: Zarzadzanie i Marketing w Erze Turbulencji. Warszawa: MT Biznes, 2009.

14. Kreikebaum, H. Strategiczne Planowanie w Przedsiębiorstwie. Warszawa: Wydawnictwo Naukowe PWN, 1997.

15. Levy D. Chaos Theory and Strategy: Theory, Application and Managerial Implications. Strategic Management Journal. 1994, 15: 167-178.

16. Lisiński, M. Metody Planowania Strategicznego. Warszawa: PWE, 2004.

17. Mitchell, J.; Russo, J. and Pennington, N. Back to the Future: Temporal Perspective in the Explanation of Events. Journal of Behavioral Decision Making. 1989, 2: 25-39.

18. Murphy, P. Chaos Theory as a Model for Managing Issues and Crises. Public Relations Review. 1996, 22(2): 95-113.

19. Mynarski, S. Elementy Teorii Systemów i Cybernetyki. Warszawa: PWN, 1974.

20. Mynarski, S. (red.). Elementy Teorii Systemów i Informacji. Äaków: Wydawnictwo Akademii Ekonomicznej w Krakowie, 1989.

21. Phaal, R.; Farrukh, C. and Probert, D. T-Plan - The Fast-Start to Technology Roadmapping: Planning Your Route to Success. Cambridge: Institute for Manufacturing, University of Cambridge, 2001.

22. Shannon, C. E. A Mathematical Theory of Communication I. The Bell System Technical Journal. 1948: 27(3): 379-423.

23. Shannon, C. E. A Mathematical Theory of Communication II. The Bell System Technical Journal. 1948, 27(3): 623-656.

24. Stankiewicz, M. J. Zarzadzanie Organizacjami w Gospodarce Opartej na Wiedzy. Toruń: Wyzwania Strategiczne Wobec Organizacji, Dom Organizatora TNOiK, 2008.

25. Thomas, J. and Mengel, T. Preparing Project Managers to Deal with Complexity Advances Project Management Education. International Journal of Project Management. 2008, 26: 304-315. 


\section{SCENARIJŲ ANALIZĖ CHAOSO SĄLYGOMIS}

Santrauka. Straipsnio tikslas yra pristatyti, kaip modifikuoti klasikinị scenarijų analizès metodą, siekiant ji pritaikyti ekstremalioms neprognozuojamoms ir chaotiškoms situacijoms. Tai yra bandymas, siekiant parodyti, kaip yra įmanoma palaipsniui prisitaikyti prie aplinkos pokyčių ir kokius metodus geriausia taikyti, kad šis prisitaikymas būtų kuo efektyvesnis. Straipsnyje parodyta, kad dèl dinaminių ir kompleksinių sąveikų, kurios būdingos nestabilioms situacijoms, galima pasinaudoti scenarijų analizès metodu, modifikuojant šį metodą kai kuriais chaoso studijų elementais.

Magdalena ADAMUS - Ph.D. Institute of Philosophy, Jagiellonian Univeristy, Poland. Research fields: philosophy of economics.

Magdalena ADAMUS - Jogailos universiteto Filosofijos instituto darbuotoja, filosofijos mokslų daktarè. Mokslinių interesų sritys: ekonominé filosofija.

Piotr MARKIEWICZ - Ph.D. Cracow Business School, Cracow University of Economics. Research fields: strategic management, implementing strategy, change management.

Piotr MARKIEWICZ - Krokuvos ekonomikos universiteto Krokuvos verslo mokykla, ekonomikos mokslų daktaras. Mokslinių interesų sritys: strateginè vadyba, strategijos diegimas, pokyčių vadyba. 